\title{
HENRIQUE ALVIM CORRÊA: GUERRA E PAZ COTIDIANO E IMAGINÁRIO NA OBRA DE UM PINTOR BRASILEIRO NO 1900 EUROPEU
}

\author{
Alexandre Eulalio
}

A obra visual de Alvim Corrêa (Rio de Janeiro 1876 - Bruxelas 1910), sob todos os aspectos pelos quais possa vir a ser considerada, apresenta caráter singular e, diria mesmo, único dentro da experiência cultural brasileira sua contemporânea. A circunstância biográfica do pintor, que na Europa se formou e amadureceu enquanto homem e artista; a existência breve intensamente vivida numa ardente interioridade; a obra complexa, que se encaminha em diversas direções e em todas elas soube se afirmar; o insulamento cultural do criador, situação que jamais chegaria a superar de todo, nos diversos ambientes por onde passou; a sólida vocação intelectual, que lhe permitiu discutir, por escrito, com lucidez e paixão surpreendentes, os problemas que a sua arte ia enfrentando; a necessidade de experimentação formal a que chega, por assim dizer, tateando, sozinho; a mesma perplexidade criadora que há de deixar em suspenso as diversas trilhas que tentou abrir para a sua obra, - fazem do visionário ilustrador de A Guerra dos Mundos, de Wells, uma figura sem paralelo entre nós.

De algum modo consciente desse fato, o 'desenraizado' esboçou de certa feita uma caricatura em que, sobre um canhão de campanha, pedestal algo instável, colocou o próprio busto com a inscrição sardônica A Alvim Corrêa/le Peuple Brésilien. O sorriso escondia, pungente, a mal disfarçada esperança de que não caísse no vazio o seu esforço criador - esforço frustro, 
partido ao meio, conforme devia lhe aparecer nas horas de desânimo, que não podia interessar tanto assim à Bélgica de "La Libre Esthétique". Talvez acabassem recolhidos, um dia, pelo país de origem dele. Ao Brasil, na época, prendiam-no apenas vagas relações familiares. Exceção quase única constituía o querido tio Artur Alvim, engenheiro ilustre, muito ativo na expansão ferroviária nacional, agora funcionando no projeto ambicioso da Vitória-Minas; "oncle" acompanhara-o carinhosamente em longas curas pelas estações de água germânicas. Relações, no mais, remotas, que talvez tivessem sido reavivadas, nos dois últimos anos de vida, com o contacto estimulante que manteve com um outro brasileiro de escola, homem de cultura humanística, colecionador avisado, este Oliveira Lima, nosso Ministro em Bruxelas. O ensaísta de Dom Pedro e Dom Miguel havia sabido apreciar os seus trabalhos e lhe deu o apoio intelectual mais importante recebido de qualquer conterrâneo nessa época. Coincidência ou não, o último desenho que o artista gizou - uma cabeça de mulher a lápis de cor - acabou sendo feito sobre um retalho de jornal brasileiro de maio de 1910, que noticiava o agravamento da saúde de Tolstoi na estaçãozinha de Astápovo, perdida nas estepes da Santa Rússia.

Falecendo aos trinta e quatro anos apenas, Henrique Alvim Corrêa deixava naturalmente uma obra fragmentária, mas sempre sutil, na afoita variedade e complexidade que a caracteriza. Iniciara o aprendizado profissional, em 1894, com Edouard Detaille (1848-1912). A tradição familiar conservava a expressão de lisonjeiro apreço que $\mathrm{O}$ autor de Rêve de Gloire e L'Attaque du Moulin teria demonstrado pelo candidato à arte da pintura, dizendo, ao mundano padrasto do jovem e fino meteco, que gostaria de possuir, ele, mestre, o talento do discípulo. Até 1898, quando se retira bruscamente para Bruxelas, rompendo com o meio que até então havia sido o seu, Henrique já expôs duas vezes no Salon parisiense - em '95 e '96. Nesta segunda vez com uma vasta composição, sempre de tema guerreiro (especialidade do seu mestre) que se impôs ao público e à crítica tradicional. Mesmo considerando com o necessário distanciamento o critério e as exigências de qualidade desse ambiente, é sem dúvida significativo o fato de o jovem Alvim Corrêa, aos 19-20 anos, ser considerado um dos melhores e mais promissores alunos de Detaille. Este havia feito ainda mais jovem a sua entrada no Salon: aos dezessete anos, em 1865. Tendo tido a honra suplementar de ver a sua primeira tela exposta, Bande de Tambours, ser adquirida pela Princesa Mathilde Bonaparte, notória incentivadora de talentos.

Ao romper com o meio onde até então havia circulado (a jovem esposa que ele passionalmente arrebata do seio da família, é filha de um gravador de certo prestígio, Charles Barbant - que Roberto Teixeira Leite 
me lembra, a tempo, ser quem transpôs para a chapa as ilustrações de Férat para L'Ile Mysterieuse, de Verne), não serão poucas as dificuldades que Alvim Corrêa terá de enfrentar na Bélgica para onde se dirige ao lado da mulher adolescente. Com o nascimento do primeiro filho, em fins de 1898, a luta pela existência torna-se pesada. A afirmação profissional do recém-chegado em uma série de trabalhos subalternos (decoração mural, desenhos publicitários) é lenta; apenas dois anos mais tarde tem lugar a transferência da família da morada provisória da Rue du Commerce, centro de Bruxelas, para o ainda remoto arrabalde de Boitsfort. Aí nasce, na entrada do século, o segundo e último filho do casal.

Dez anos transcorrem depressa, e apenas mais dez anos havia de viver o moço pintor, 3 que a partir de 1905, minado por uma tuberculose fatal, tornar-se-ia quase um inválido. Mas dez anos para um artista cheio de talento, que sente em si reunidas, apesar da saúde frágil, as forças da idade e do talento, pode significar muito. Nos seus dez anos bruxeleses Alvim Corrêa vai realizar uma obra notável pela força e pela originalidade. Ilustra A Guerra dos Mundos, de Wells, organiza uma exposição individual, em 1905, e uma coletiva, em 1910, torna-se gravador muito competente, escreve com freqüência observações sobre o seu ofício, e pinta e desenha sem descanso.

Nas páginas em que reuniria as reflexões nas quais abordou temas como o fazer e o representar na pintura, aparecem nítidas não só as dúvidas que assaltaram o artista no ambiente belga, durante o seu processo de amadurecimento, mas ainda a insistente fidelidade não tanto à doutrina, mas aos ensinamentos práticos do seu primeiro aprendizado; o pintor insiste em aproveitá-los, torná-los mais flexíveis, adaptando-os, da melhor maneira que podia, ao novo sistema criativo a que aderiu. Nesses escritos teóricos surpreende a densidade do questionamento íntimo. Sem pretenderem maior transcendência, enfrentam eles, com simplicidade, dilemas e hesitações das artes visuais. A medida da coordenação do discurso reflexivo de Alvim Corrêa e a continuidade do seu meditar, no nível problemático de teoria e prática, aparecem inequívocos nessas notas. A intensidade quase passional da crítica e da observação do artista possui uma qualidade stendhaliana; uma e outra, observação e crítica aí comparecem expostas, contudo, com espírito pedagógico e sereno tom didático. Entre os muitos textos que viria a redigir - diversos de caráter literário, incluindo peças de teatro em que discute problemas sociais possuem relevância especial os quase-aforismas reunidos em Recueil de verités et observations sur l'art, le dessin et la peinture, que o autor dividiu em 10 capítulos e 442 entradas de extensão irregular. Um documento que 
constitui, ao mesmo tempo, suma e fé de ofício do seu próprio pensamento, e que ele fora redigindo ao longo dos primeiros anos do século.

No campo da produção artística propriamente dita, apesar da brevidade do tempo que dispôs para a compor, e das condições adversas em que a concebeu, Alvim Corrêa deixou obra que se abre num leque multiforme de direções, sem prejuízo da coerência íntima do conjunto. Além dos vários estudos de tema militar, gênero que não há de abandonar de todo até o fim da vida, trabalha nesses anos em desenhos e óleos de fatura requintada e fino acabamento, muitos deles de caráter experimental, sobre paisagens reais ou fictícias. Daí passa, com natural volubilidade para o devaneio imaginativo, cenários de sonho, ambientes fantásticos, figurações ideais, desentranhadas muita vez da superfície de uma encosta ou das manchas de um muro. Exercícios que o tornam habilitado, a mão sempre mais ágil, para ilustrar, com delicadeza e fantasia, contos de fadas, estórias fantásticas, narrativas sobrenaturais, sem perder nunca a ponta de humorismo e malícia necessárias para garantir um pé fincado na terra. Capacidade de abstração e imaginativa ardente permitem-lhe conceber ainda alegorias e personificações simbólicas que podem abarcar o patético e o grotesco com idêntico poder de convicção.

O clima febricitante do terror ou a atmosfera de transporte erótico ele os consegue recriar com a mesma facilidade com que desliza para o campo da paródia ou da caricatura. Alguns retratos sarcásticos, que executa a nanquim e realça com aquarela, podem absorver o riso crispado de cruas representações libertinas. Estas últimas ele as fazia assinar pelo seu alter ego Henri Lemort, timbrando sobre o monograma HL o perfil ora de uma caveira, ora de certo petulante sapato feminino de salto alto. Com o mesmo à-vontade chega aos apontamentos ágeis do dia-a-dia, com aquarela, nanquim ou carvão, indiferentemente; flagrantes delicados, de um intimismo poderoso, onde os pequenos gestos como que recuperam o sossego da plenitude. Em torno de algumas dessas personagens o pintor reconstrói a paisagem que as envolvia, no campo ou na cidade - paisagem convulsionada pelos combates, nas primeiras telas de Alvim Corrêa. Já o tema da conflagração, que tanto o havia interessado, ele há de transfigurálo, numa outra e mais terrível guerra, nas assombradas ilustrações para o romance de Wells, The War of the Worlds. A unidade desses desenhos, de poderoso contraste tonal - um crítico contemporâneo chegou a falar no 'colorido' dessas composições em branco e preto -, e que se encadeiam independentemente da seqüência narrativa do romance, e constituem, realmente, uma das mais completas realizações doartista, queas concebeu, na sua forma decisiva, de 1902 a 1904. Por meio desta primeira tentativa de abordagem do mundo que Alvim Corrêa esboçou, em condições 
freqüentemente penosas, quando não de todo adversas, verificamos que o interesse de uma obra como a sua ultrapassa uma primeira impressão de disponibilidade brilhante, permitindo que no pessimismo desencantado do artista seja detectada e abordada criticamente toda uma gama de significações ainda secretas.

A guerra foi o tema que primeiro abordou o jovem Henrique, naturalmente levado a ela pelo fascínio meio irresponsável que experimenta qualquer adolescente pelo confronto armado em si, no qual investe a própria agressividade. Não é improvável que derive, ainda, da impressão esmagadora que teria causado, ao colegial de Nova Friburgo, em férias na Corte, a pompa triunfalista das batalhas de Pedro Américo, patrioticamente expostas na pinacoteca da Academia Imperial de Belas Artes. Mas dentro desse envoltório de fascínio gratuito talvez tenha pesado também, em Paris, no ambiente demagógico de revanchismo gaulês anos '9o, a vontade do moço estrangeiro de se afrancesar mais depressa, a fim de superar o sentimento sufocante, mais desagradável do que nunca na “idade de cera”, de ser considerado estranho, 'alienígena', no ambiente em que vivia. Seguindo sempre nessa mesma ótica: o tema da guerra, além de apelar para a generosidade disponível e o espírito de aventura dos anos formativos, corresponde à resposta bom-escoteiro ao desafio existencial, maneira Jules Verne, onde a coragem se identifica com o sublime. Enfim: a guerra vista como "férias grandes", cheia de imprevistos e extraordinárias aventuras, nas quais o eu-protagonista invariavelmente sai incólume e triunfador.

Mas o tema da conflagração armada trazia no bojo, para a sensibilidade atenta deAlvim Corrêa, em toda a irracionalidade dela, a questão do destino pessoal, da existência concreta na sua circunstância, colocando em foco, sem disfarce, o desamparo do homem diante de todos os imponderáveis. Elementos de decisiva importância para a pré-história da sua obra, os quadros de temática bélica do jovem artista que até nós chegaram, ou dos quais possuíamos documentação fotográfica, muito cedo não vão refletir mais o heroísmo sedutor e reluzente da batalha - especialidade do seu mestre Detaille, cuja sobriedade elegantíssima adula o observador. Muito pelo contrário, possuem eles um geral aspecto sombrio, misto de desalento e desamparo, exibindo pormenores cruéis que deviam deixar algo perplexos os amigos dos Oliveira Castro. E se, por diversas vezes, a ambientação de que vai utilizar-se o moço brasileiro nesta fase, aproveita sugestões cenográficas menos do próprio Detaille que de certo Alphonse de Neuville (ângulos de rua em cidades semi derruídas pela metralha; cemitérios onde a ação militar prossegue profanando túmulos que a neve cobriu; soldados que aguardam o amanhecer acantonados no frio, atrás de 
um muro - situações, todas estas, caras ao pintor de La Défense de la Porte de Longboyau e Le Cimetière de Long Privat), tom narrativo e tonalidade pictórica mantêm-se quase sempre soturnos. Torna-se antes de mais nada visível o caráter brutal da violência. Mortos ocupam o primeiro plano. Encolhidos sobre si mesmos, os combatentes encontram-se na defensiva. Dissimulam-se mais do que se destacam em meio ao casario esborcinado, como peças de um jogo sem razão de ser. No qual assistimos a inúmeros figurantes serem eliminados em cena aberta. O peso da melancolia nessas paisagens imersas na escuridão, que a neve suja de lama e sangue esbate, num palor mortiço, não deixa dúvida quanto à crise vivida pelo autor. Nessa ocasião, prosseguindo no mesmo estilo de ilusionismo perspéctico, de estrita obediência acadêmica, pinta esquinas anônimas de uma cidade vazia, um cemitério - este entregue aos legítimos donos - sob a neve. Temas noturnos, que regressarão mais tarde, num contexto diferente seja do ponto de vista formal seja do conteúdo, naquelas composições em que, ao cair da noite ou madrugada alta, uma janela acesa instala na obscuridade um marco de alento, de aconchego.

Passar-se-ão alguns anos até que o Esboço de Panorama do Assédio de Paris trate, de maneira bastante diversa, o mesmo assunto; agora com absoluto à-vontade, que se reflete na soberana perspectiva aérea do conjunto, distribuído com amplo fôlego por sete painéis. Aí, quer pela alacridade das cores empregadas, quer pela vivacidade ambiguamente maliciosa com que foram dispostos os grupos humanos (que não exclui pormenores de agressividade mórbida), a paisagem, na amplidão dos seus acidentes topográficos, esparsa a se perder de vista, mesmo insultada pelos obuses e pela metralha, que enchem o horizonte de flocos brancos - parece soberanamente indiferente a esses implacáveis fantoches que se eliminam uns aos outros com um rancor odiento. E o artista, como por acaso, não nos priva dos pormenores dessa fúria a frio. $\mathrm{O}$ mais chocante deles será o do soldado caído de joelhos, sustentando-se mal e mal com os dois braços, de cuja cabeça, atingida por um disparo, o sangue goteja monstruosamente, empoçando-se por terra. Minúcia que, entre outras, pretende desmanchar a ilusão... de ótica que nos fez julgar apenas um brinquedo inocente esse projeto meio ocioso de panopticon.

Neste, como em outros exercícios pictóricos, Alvim Corrêa buscou reconstruir o modelo que esboçava, realizando-o na tela de maneira rápida, em sucessivas pinceladas livres, através de experimentações que, por certo, foram encaradas pelo nosso criador enquanto experimentos marginais, testes de bravura e de domínio do medium. Pequenos esboços a óleo realizados sobre tela nua estão datados dos últimos anos do decênio de '90; penso num franco-atirador mal enfardado em roupas 
desencontradas, fuzil à bandoleira; num suboficial prussiano a meio corpo, cachimbo de louça à boca, atrás do qual uma heráldica águia negra foi reduzida, em agressiva simplificação, a um frango faminto. No Panorama de Assédio a figura humana, miúda na paisagem, vem tratada de modo conciso, numa concepção dinâmica quase à maneira da gravura japonesa dos imitadores de Hokusai - um Hokusai que houvesse estudado Gavarni e Daumier. Mobilidade angulosa em que um comentador bruxelense, de 1905, reconheceu certa ironia. Característica que deve provir da mescla de aceitação-piedade-indiferença que o inventor da cena devia sentir pelo patético e inútil agitar-se daquelas figurinhas, que provocam sorriso e pesar ao mesmo tempo.

Conforme já sugerimos acima, seja nos óleos seja nos desenhos, Alvim Corrêa preferiu sempre à técnica de Detaille a pincelada mais livre, de tradição ainda tardo-romântica, de Alphonse de Neuville (1836-1885 - a quem, portanto, não chegou a conhecer). Neuville e Detaille, "os dois primeiros pintores militares do tempo", - conforme regista E. Bricon na finissecular Grande Encyclopédie, coordenada por Poincaré, - apesar das diferenças do fazer pictórico haviam colaborado, em 1881, num vasto painel circular que então causou entusiástico furor, o Panorama de la bataille de Champigny. Uma tela na qual, segundo o mesmo Bricon, "la fougue et la verve de Neuville s'unissaient à la correction et à la précision de M. Detaille". Embora concebido num espírito muito diferente, no qual não falta certo sentimento sardônico, o Panorama do Assédio teve de ser motivado pela famigerada obra a duas mãos - não importa se até com certo espírito contestatário. O posicionamento de Alvim Corrêa relativamente à temática guerreira a partir de certo momento é problemático; ela atrai-o e por ela ao mesmo tempo sente repulsa. Parecendo superá-la, desde os primeiros anos do século, a favor de um enriquecimento temático que se encaminha para horizontes diversos, não deixará de voltar a ela, que assim permanece um dos motivos condutores da sua obra. Ainda de 1908, datados ao pé da página, existem belos desenhos aquarelados de militares como que surpreendidos na intimidade do quartel. Aliás, o pintor diversas vezes aborda aspectos da simplicidade, do estoicismo, da fraterna camaradagem castrense, anverso de moeda cujo reverso são os aspectos ridículos ou diversamente risíveis da prepotência, vaidade e vazio das falanges gloriosas. Aspectos que não podiam escapar ao olho alerta de um caricaturista malicioso.

Para esses exercícios gráficos tardios continuou a servir-se (seguindo o exemplo de Detaille) de um manequim maleável, com cabeça e mãos esculpidas, que mantinha no estúdio. As molas engenhosas do bonifrate permitiam dispô-lo nas mais diversas posições, atitudes e contrações 
corporais. O pintor fotografou-o fardado de zuavo, fumando, um dos braços a se apoiar nas cadeiras e, também, agachado em posição contorcida, as mãos firmadas nos joelhos, como a olhar por um desvão demonstrações práticas daquilo que lhe podiam oferecer os engonços do boneco. Conservava também grande variedade de armas autênticas com o mesmo fim - outro vezo que herdou do mestre. Aparece este representado numa tela de Lemeunier (reproduzida no volume En Campagne. Tableaux $\mathcal{E}$ Dessins de Edouard Detaille, texto de Frédéric Masson, - um álbum de reproduções que Alvim Corrêa possuía) pintando no seu estúdio entre uma série de capacetes, quépis, dólmãs, couraças, talabartes, sabres, cimitarras, armaduras dos séculos XVI e XVII, que dariam para fazer a felicidade de muitos fetichistas de todos os sexos. No belo desenho em que Alvim Corrêa representou o atelier de Boitsfort - hoje integrando a coleção do Museu Nacional de Belas Artes - é fácil divisar, no varandim rústico que corre pela empena do lado esquerdo do estúdio, a fila de mosquetes espingardas e fuzis, alguns calados com baioneta, que ali se encontravam não como elementos de decoração ambiental, mas enquanto elementos justificativos de sempre possíveis composições guerreiras. Durante a exposição que organizou dos seus trabalhos, em 1905, numa galeria bruxelesa, não hesitou em colocar no centro da sala - a nosso ver com evidente intenção polêmica - um 'troféu' em que se confrontavam um capacete prussiano e um quépi francês. A provocação causou o efeito desejado. Escandalizou um dos críticos locais. O qual, com apressada e superior ironia, desaprovou o provinciano vieux jeu tanto mais porque provinha de um membro da nova geração, - qüiproquó que muito divertiu o nosso herói. Algo mais do que curiosidade pitoresca ou fortuito desorientamento, a dividida fidelidade de Alvim Corrêa à sua formação como pintor merece ser estudada com atenção.

As ilustrações para A Guerra dos Mundos retomam a temática da refrega, absolutizando-a e paradigmatizando-a como catástrofe total. $\mathrm{O}$ artista identifica-se de maneira fervorosa com o tema wellsiano. Produzirá, com imediato poder de convicção, em formas concisas, ao mesmo tempo irônicas e extravagantes, a representação plástica da tecnologia marciana, emblema eloqüente da arbitrária vontade de domínio de uma cultura superior. Concebidos no patético claro-escuro de Alvim Corrêa, tais espectros da fantasia tecnológica - pesadelo veemente na infância da era da máquina, cujo alcance compreendemos hoje sem dificuldade -, assumiam para o leitor presença empolgante, impetuosa. Embora The War of the Worlds (1898) não possua nem a beleza vertiginosa nem a densidade de conto filosófico inseparáveis na obra-prima de Herbert George Wells - Time Machine (1895), ficção cuja 
ácida parábola política é tão clara como convincente -, não é impossível ver uma metáfora da opressão tecnocrática nessa fantasia aterradora, que se conclui, all's well that ends well, com o colapso desses seres apenas cérebro, portanto apenas-gerência, apenas-hegemonia, apenas últimasdecisões-indiscutíveis. Medusas-do-mar transplanetárias, os invasores, com plataformas-palafitas ambulantes, tentáculos de manipulação, cilindros-automóveis que trouxeram do planeta deles, numa primeira transferência de tecnologia, tudo violam, destroem, dominam, numa sede de aniquilamento inédita. Fornecem, destarte, ao ilustrador gráfico, visões em que claro-escuro, reflexos, lucilações, contrastes de superfícies e materiais - chapas metálicas, vegetação, cantaria, madeira, água - são utilizados com grande beleza e funcionalidade. A cerebrina concepção alucinatória da aparência física dos invasores e a simétrica humanização da máquina deles (o teto em funil raso das palafitas ambulantes lembrando o chapéu dos chins; as clarabóias de bordo tratadas como olhos vigilantes; as longas pernas articuladas das plataformas) acrescentam uma aura de terror totêmico e regressivo deveras apavorante. Mais do que nunca sentese o homem inerme diante da força esmagadora que invade e oprime o seu cotidiano. Tremendos semideuses de uma outra Era Mesozóica subitamente enxertada na História, será necessário submeter-se a eles ou descobrir alguma maneira, ainda desconhecida, de os espatifar.

A veemência visual do artista adere assim a um pretexto narrativo que lhe iria propiciar determinada explosão de criatividade febril. Além das larvas do inconsciente, nesses desenhos arrebatados retornam não apenas elementos da tradição gráfica Hugo-Daumier-Doré, claramente presentes em pormenores da feitura, mas, sobretudo, sugestões intimamente ligadas à experiência cultural com que Alvim Corrêa se identificava, do ponto de vista ideológico. Em primeiro lugar o Rops metafísico - e de modo muito preciso, aqui, o Satã semeando cizânia, do mestre flamengo, que creio ter tido, neste caso específico, função icônica geratriz, mesmo se tal liame não foi conscientizado no brasileiro. Em seguida Redon, com o eloqüente silêncio das séries de álbuns dele - Em pleno sonho, Para Edgar Poe, As Origens, Homenagem a Goya, Tentação de Santo Antão -, sementeira inesgotável do Decadismo 1870-1910, de quem foram os livrosdehora leigos. Diversos dos emblemas que Redon cifrou nas obras acima são aqui desenvolvidos e reintegrados com originalidade por Alvim Corrêa no fragor e furor de uma ação frenética, contínua, virulenta, que vale em si mesma pelos humores que movimenta e liberta. Simbolizando ruína e tirania, a opressão do invasor convulsiona cidade e campo, desenfreia um horror coletivo. O inventor dessas visões de flagelo, ao representá-las, não desprezou imagens tradicionais ligadas ao macabro, ao grotesco, ao 
calafrio - revoada de morcegos, esqueletos fumegantes, aves carniceiras sobre corpos putrefactos. O artista aproveita todas as oposições, todos os contrastes de textura, de densidade matérica, superfícies foscas ou espelhantes, negror de treva e luz ofuscadora. Joga até com a rutilância e o dispersar centrífugo do impacto explosivo que, para o observador, precede de um segundo a detonação. Uma das mais belas imagens da série vem a ser aquela em que, na fímbria de bosque espesso, cortado por um riacho, a palafita marciana emite luminosidade fulgurante que, à direita, dimana livre pelo campo aberto mas, à esquerda, refracta-se, em estrias e manchas, nos troncos das árvores esgalgas e na água corrente. Não fosse a revoada de corvos minúsculos baixando, ao fundo, sobre imperceptíveis marcianos, e duas palafitas agora reduzidas a sucata metafísica (talvez a primeira representação de um "cemitério de automóveis" nas artes visuais do séc. XX), outra dessas ilustrações seria um perfeito estudo abstrato de superfícies e profundidades. Estudo estupendo de tramas, curvaduras, rebitas, alombamentos, concavidades, socalcos, arcabouços metálicos e lígneos, realizado com inteiro domínio técnico; das raias unidas do azurado à sombra difusa do carvão, todas as técnicas do desenho estão aí presentes, transfigurando esse vale escarpado de iconografia romântica tradicional, de que os marcianos de Alvim Corrêa se agradaram. E tudo converge para o espaço central onde vasto poço, cheio de mistério, ordena com a sua polida circularidade platônica de granito ou aço (minha vista não dá para distinguir) o desalinho ambiente. Sobre o mar uma forma esférica flutua, todas as fibrilas pendentes, como uma anêmona das profundas aureolada por um anel-de-saturno. Poderia haver mais explícita homenagem de Alvim Corrêa a Odilon Redon? Uma espécie de sortilégio tudo enfeitiça nessas ilustrações. Mesmo as coisas inertes, num delírio alucinatório, metamorfoseiam-se: a cúpula maciça da catedral se transmuda numa caveira gargalhante e as janelas acesas da rua devastada são olhos em pânico, que o terror arrancou das órbitas (“... partout des prunelles flamboient...") ${ }^{1}$

$\mathrm{O}$ regresso à ordem primordial tem lugar por um reequilíbrio do metabolismo interplanetário, que reinstala a velha respiração compassada dos mundos, que a hubris dos invasores pretendeu transgredir; acompanhando o escritor, o desenhista concede restaurar, nas últimas ilustrações, o velho ritmo do nosso sistema solar. E junto da palavra FIM (que em francês vale também para "fino") inscrita na capa posterior de um vasto caderno, Alvim Corrêa retratou a Wells e a si mesmo. O 
romancista, em mangas de camisa, está pisando os restos mortais de um dos tecnocratas marcianos, enorme pena-de-pato (proporcional ao caderno antes referido) debaixo do braço. Sentado no chão, de pernas cruzadas, o pintor é uma - Flaubert, St. Antoine. concentração só - testa franzida, maxilar tenso -apontando, num bloco de desenho, as feições do intelectual que tanto admira. Creio que se possa chamar esta cena, com todas as letras, happy end.

A repugnância, inseparável do fascínio, que ao artista inspira o sentimento de onipotência desses seres, que contra tudo investiam com descaso olímpico, informa com eloqüência, ainda que de maneira transposta, sobre a preocupação com a insuperável sensação de vulnerabilidade do homem no mundo, decisiva nos significados da obra de Alvim Corrêa. Através de todas as áreas temáticas pelas quais se estende a obra multifária do nosso artista - cenas de combate convencional da guerra oitocentista (1870, Port-Arthur), paisagens do Brabante e da Flandres, cenas eróticas, esboços intimistas, aspectos da rua, visualizações convulsionadas de maquinismos monstruosos, alegorias contestatárias, simbólicas personificações - parece prevalecer sempre a esmagadora certeza de se sentir joguete de forças que dele podem dispor com absoluta impunidade, forças às quais ele se encontra submetido e com quem não pode lutar.

Henrique Alvim Corrêa, menino bem nascido 'numa província ultramarina', provinha de ambiente convencional e conformista. O meio exílio voluntário que a família resolvera assumir após a queda do Império veio a lhe propiciar formação artística européia nada rotineira; o jovem pintor jamais deixaria de ficar efetivamente dividido entre o estímulo que recebeu nesse meio eas novas experiências por que passou, após abandonar o berço esplêndido onde havia nascido. As dificuldades de integração num outro mundo, obrigatoriamente conflituosas, neste caso farão dele um temperamento de tendência anarcóide, cheio de inquietação e revolta, simpatizante platônico de lutas sociais e campanhas progressistas. Ao mudar radicalmente a direção e o espírito da obra artística que vinha empreendendo, procura voltar-se, com idêntico interesse, para as mais diversas áreas da cultura, num dramático afã de melhor se conhecer, até se encontrar de todo.

O cotidiano, por exemplo, é um território que só então passa a lhe dizer respeito. Aceita, com vigorosa disponibilidade, esse primeiro desafio. Anota a vida circunstante com agilidade e senso de humor. Observa-a, às vezes com mal-disfarçado sarcasmo, outras com interesse de miniaturista, sempre com viva emoção. Volta-se para os meios populares e operários, dos quais executa, dentro desse espírito intimista, impetuosos 
esboços e perfis; parece haver reaproveitado alguns deles no contexto de composições, encomendas ou ensaios de ilustração para revistas de grande tiragem. Salvo erro, não teve oportunidade (ou curiosidade) de se voltar para a comunidade camponesa. Muito diversificada num país de velhas raízes culturais como a Bélgica, esta deveria chamar a atenção fosse pelo simples pitoresco de experiência nova, fosse por constituir um tema ilustre da pintura - a um brasileiro, mesmo desenraizado. Do campo apenas a paisagem parece ter-lhe interessado; procurou seguidamente captar o seu espírito num amplo ciclo de óleos de interesse desigual.

Esse memorial do dia-a-dia, apontamentos em que começa, em alta dose, a simplificar e a estilizar os modelos, caminha naturalmente para outros domínios. Adota a caricatura, para a qual tem muita garra, como uma espécie de taquigrafia; explora-a, seja a propósito de situações concretas seja em fantasias morais na linhagem nau-dos-tolos, elogioda-loucura. Muito de época, também, o anticlericalismo do autor; desejando-se cáustico, é francamente convencional, não importa a finura humorística dos seus apontamentos, ora imaginários, ora tirados de modelos. No desenho erótico o autor - ou melhor H. Lemort - praticou dois níveis de realização, um mais faceto, voltado para certa literalidade as mais das vezes crua, e um segundo patamar, onde perplexidade e melancolia se mesclavam, e cujo núcleo era o diálogo Eros-Thanatos. A gratuidade e mesmo o mecanismo do frêmito erótico são encarados como parte integrante, inalienável, da condição humana. Ao abordar aspectos do grotesco fronteiriços ao monstruoso, obsessões e fantasias desgarradas, mesmo quando utiliza um grafismo levemente arrebitado, de sabor ligeiro e jornalístico, trata de fazê-lo com um tato e um sentimento de respeito que tornam deveras singular a sua experiência no gênero. Autor convincente de alegorias, que na sua pena possuem autoridade que impressiona, realizou também algumas, nesta área, que constituem altos momentos. Inesquecível, na verdade, a representação paradoxal da fragilidade e da intensidade do prazer, em certo desenho de H. Lemort, talvez a obra-prima do heterônimo maldito. Investida por um cupido, que mergulha sobre ela, uma dona em transe, cabeleira solta sobre um lençol que espadana ao vento, firma os pés crispados sobre uma caveira enorme, meteoro velocíssimo que atravessa e a leva espaço afora.

Das fantasias ligadas às pulsões íntimas passaria ele para a área (de certo modo limítrofeà anterior) das personificações simbólicas quea Alvim Corrêa só interessariam referindo-se diretamente a mazelas e problemas sociais candentes. Estreito que ele transpõe com felicidade reutilizando sem servilismo, mas enquanto discípulo confesso, outro setor da tipologia visual de um Félicien Rops. O relacionamento que estabelece com o tema 
alegórico, contudo, é sombrio e possui o próprio timbre. "No Pelourinho", "Vae victis!", "Amazona triunfante", "Vá, já é hora!", transposições icônicas de problemas explosivos - a Mulher vítima, a Mulher súcubo, a prostituição, exploração social -, possuem autêntica força encantatória e mesmo certa aura hipnótica. Através dela adivinhamos o interesse de Alvim Corrêa pelo imaginário em estado puro - estórias da Carochinha, fantasmagorias - que também ilustrou em diversas ocasiões, talvez por encomenda de terceiros, talvez por iniciativa própria. "Aprendiz de necromante" aproveita a vertente irônica do seu temperamento; "A Hora dos Grilos", " Casa Redonda”, fantasias risonhas inseparáveis do aspecto anterior. É ainda o caso de "A Abelha Obediente", narrativa infantil: uma fadinha alada ordena, dedo em riste, que a sua abelha de estimação se chegue mais para perto ("Aqui! aqui!", parece dizer) no tom de comando (de quem se dirige ao cachorro de casa, totó ou buldogue. Construída com traços guilhoqueados em nanquim, apesar do caráter ameno que apresenta, neles aparecem vetustas raízes intumescidas, misteriosas, que em certos desenhos do autor estão presentes a fim de criar certo clima encantatório, certo lusco-fusco da consciência.

Inequívoca conotação ctônica apresentam alguns estudos livres da natureza feitos a lápis. Linhas de força de troncos de árvore, em que o efeito das hachuras desencontradas, definindo raízes, galhos e, ainda, bossas, cavidades e ocos de um velho tronco, possuem objetividade mágica eminentemente táctil. Da representação de florestas anosas e compactas, de um pormenor prestigioso de potentes raízes centenárias, expostas à flor do solo, evola-se intensa sugestão de sortilégio, que muito se deve à execução enérgica do desenho. Mais instigantes ainda serão talvez as silenciosas insinuações de descida ao subconsciente que se contêm num outro desenho, este de poder quase sibilino: "A Grande Escada" talvez primitivamente ilustração original para conto fantástico ou de um elaborado poema simbolista. Raízes enodoadas começam a romper parapeitos e lajes de monumental escadaria em pedra, que se perde, infinita entre bastas árvores, na montanha íngreme; uma dessas raízes já atravessou o anteparo da mureta e se espoja ao sol, por sobre os degraus inferiores, enquanto mais outras, próximas, preparam-se por sua vez para o ataque. Imagem pungente da construção intelectual e sobranceira, inevitavelmente corroída e por fim destroçada pelas forças do instinto, é bem expressiva da filosofia do ilustrador de A Guerra dos Mundos.

Alvim Corrêa cultivou ainda alguns desenhos a cor - de sabor naturalista e temário patético -, visando talvez a motivar suplementos de jornais com uma grande tiragem. Neles a violência é surpreendida em diversas gradações sadomasoquistas; também foram registrados 
momentos de perplexidade cheios de sutileza. Sempre no campo gráfico, cenas de multidão, cenas de rua, vastos grupos em interiores públicos, são recriados com humor rascante; o traço anguloso é rápido e o realce colorido amigo de estridências. Possuem caráter parodístico, bastante próximo, em certos casos, de algumas das representações da área erótica.

A paisagem (outras vezes a figura dentro da paisagem) é tratada como estado d'alma. Diversos estudos de vegetação rala e engrouvinhada desenvolvem-se em elaboradas recriações quase abstratas; ramaria egalhos secos unem-se num emaranhamento irisado que merece do artista atenção e capricho caligráficos. Tais estudos aproximam-no da pintura oriental; mas se esse japonismo chega ao pintor pela via realista do apontamento da natureza, logo é retomado à la manière de, seguindo a moda elegante do tempo. Outras telas, pela violência do gesto e utilização de tons baixos, de um dramatismo denso - renque de árvores esgarçadas, bosques formando ilhas na campina, manchas remotas da vegetação de porte - aparentam afinidades exteriores com o Expressionismo; na verdade o seu pathos é, em tudo, simbolista. Em mais outras, a perspectiva se alonga através da planície movimentada, campos de plantação que se acabou de mondar, onde se levantam cabanas camponesas ou construções suburbanas que, de súbito, ganham proporção monumental graças a sua mole cúbica. Algumas dessas paisagens são autênticos estudos de matéria, espalhada em largas superfícies pela espátula enérgica, que acomoda céus, terras, águas numa só respiração compacta; possuem elas afinidades com o tratamento do mural, apesar do apelo que o pintor faz freqüentemente a tons sombrios. Já em outras composições, a escuridão é predominante; apenas uma janela, às vezes uma porta aberta, de onde provém claridade; na superfície restante, certa indefinição de espaço. Telas há que talvez não tenham recebido a última demão do autor. Nestas o perfil marcado da massa dominante (silo, curral, quartel) é definido por uma linha envoltória densa, à maneira dos mestres de Pont-Aven. Construções camponesas e terreiros de plantio da campanha brabançona ou antuérpica aparecem indicados em riscas paralelas, num traço agora quase vangoghiano. Em cores frias, distantes, mas extremamente requintadas, as paisagens de Boitsfort, residência do artista, são realizadas com notável finura e delicadeza quase amaneirada.

A posição de Alvim Corrêa diante da vida transparece com nitidez na obra que nos legou. Nesta é evidente a derivação baudelairiano-decadista, e, nesse sentido, o artista foi bem um homem do seu tempo. Pessimismo e negativismo foram experiências que ele viveu e as experimentou dramaticamente, representando-as, ora cifradas, ora com toda a transparência, em quadros, desenhos, gravuras que honram o seu autor e 
a arte brasileira. Esta soube festejar o filho pródigo, dando lhe, à mesa, o lugar que era seu de direito.

Ao deixar Paris eescolher Bruxelas, em 1898, teria o jovem Alvim Corrêa noção de estar-se abrigando numa das encruzilhadas mais dinâmicas da modernidade '190o'? Até que ponto saberia estar-se dirigindo a um ambiente privilegiado que, nesse preciso momento histórico, vivia certa experiência criadora de algum modo decisiva na evolução da arte européia? A meio-caminho entre as culturas francesa, inglesa, alemã e escandinava, com velhos e profundos contactos culturais com a Itália e a Espanha, idealmente eqüidistante de todas elas, a "jovem Bélgica” encontrava se em meio a uma decisiva avaliação crítica do próprio passado, ambicionando recuperar no campo das artes o prestígio e a projeção da velha Flandres.

Já em 1884 criava-se o "Círculo dos XX" que, até 1893 (quando se dissolve), em torno do patriarca Wille Vogel (1836-1896) reúne as figuras de Théo van Rysselberghe (1862-1926), James Ensor (1860-1949) e Georges Lemmen (1865-1916); com o apoio da revista L' Art Moderne, de Octave Maus, Edmond Picard e Emile Verhaeren, depois de promover dez salões de arte contemporânea, Les $X X$ transfundem-se numa associação ainda mais abrangente que há de se intitular "La Libre Esthétique". Esta, de 1894 a 1914, reunirá, em 21 magnas exposições, tudo o que de mais vivo e experimentador existe no país, ao lado das novas tendências que se vão afirmando na arte européia. Mas ao lado dessas agremiações decisivas pululam na Bélgica inúmeros pequenos sodalícios artísticos, alguns de caráter nitidamente político, contestatário da ordem burguesa triunfante, cuja função vai se demonstrar decisiva na formação de vários artistas de origem popular. Entre os decênios de '80 e '10, na capital e em Antuérpia, principalmente, ganham vida própria e influem no ambiente grupúsculos artísticos que são apenas, quase sempre, oficinas de trabalho ou academias livres. Nestes centros, contudo, hão de perfazer as primeiras armas diversos pintores que se afirmam mais tarde nomes de primeira plana na arte nacional: o "Voorwarts", o "Pour l'Art", a "Association pour l' Art" antuerpiana, o grupo 'L' Estampe", a "Academie Libre”, o "Cercle l' Effort", o "Cercle Le Labeur", são alguns, entre outros que seria ocioso enumerar. Em torno de Emile Claus (1849-1924), que se retira para o campo, reúnese, em Astene, o grupo tardo-impressionista "Vie et Lumière". Em breve, a partir de 1900, uma outra comunidade de artistas juntar-se-á, não longe de Ganda, na paisagem ainda mais idílica de Laethem-Saint-Martin, povoação debruçada sobre o curso remansoso do Lys. Desta vez à volta de outra figura patriarcal e assumidamente "antiga" - Albin van den Abeele (1835-1919), "ce douanier Rousseau flamand", na frase de Paul Fierens -, motivado pelo revisionismo espiritualista e tradicional de George Minne e 
do poeta Karel van de Woesteijne (mais velho e um pouco mentor do irmão Gustave), congrega-se Valerius De Saedeleer. Algum tempo depois vêmse ainda estabelecer em Laethem três outros jovens pintores, destinados porém a uma evolução muito diversa do erudito, rigoroso, despojado neogoticismo do grupo de Minne: Frits van de Berghe, Gustave De Smet e Constant Permeke, antes de 1914 - data que interrompe a evolução natural da arte belga, e não só belga - bem mais próximos do luminismo de Emile Claus do que do sintetismo simbolista de Minne.

Contemporâneos imediatos de Alvim Corrêa, nascidos entre 1866 e 1886, encontramos, assim, ativos nesse ambiente, os seguintes nomes que viriam a contar na crônica da pintura belga: além de Eugène Laermans (1864-1940) e George Lemmen (1865-1916) temos George Minne (18661941), Valerius De Saedeleer (1867-1941), Auguste Oleffe (1867-1931), Jules de Bruycker (1870-1945), Henri Evenoepel (1872-1899), Hippolyte Daeye (1873-1952), Louis Thevenet (1874-1930), Gustave De Smet (18771943), Isidore Opsomer (1878-1952), Willem Paerels (1879-1958), Leon De Smet (1881-1952), Gustave van de Woestijne (1881-1947), Rik Wouters (1882-1916), Frits van de Berghe (1883-1939), Constant Permeke (18861951). Ensor, que nasceu em '6o, Van Rysselberghe, em ‘62 e Van de Velde, em '63, precedem de pouco estes limites geracionais que não podem ser indicados senão como meramente sintomáticos. Sejam lembradas ainda outras personalidades contemporâneas ligadas às artes decorativas e à arquitetura do Modern Style, como o já citado Van de Velde (1863-1957), Victor Horta (1861- 1947), Paul Hankar (1859-1901), Georges Morren, Anna Boch (1848-1933), Alfred William Finch (1854-1930), nosso já conhecido Georges Lemmen, e o grupo que joga na área decadente-simbolista, impregnado de uma compreensão literária da pintura - Xavier Mellery (1845-1921), Fernand Khnopff (1858-1921), Charles Doudelet (1861-1938), Emile Fabry (1865-1966), Jean Delville (1867-1953), Degouve de Nunques (1867-1935), Henry de Groux (1867-1930) até Léon Spilliaert (1881-1946). Uns e outros completam a complexa topografia artística da Bélgica, 188o1910.

É neste ambiente estuante de animação, mas decerto desorientador para a experiência pregressa do jovem pintor brasileiro, que Alvim Corrêa vai ter de definir a si mesmo, revendo criticamente o seu aprendizado parisiense. Para uma primeira reconstituição do itinerário intelectual belga do moço brasileiro ser-nos-á extremamente útil o caderno de endereços onde anotou, na ordem em que foi conhecendo ou necessitando registrar, as direções de pessoas e instituições que interessavam seja à organização da casa seja à vida intelectual do artista. Essa caderneta parece ter sido iniciada quando da instalação familiar, em Boitsfort, arrabalde de Bruxelas, 
ou logo depois - portanto em 1901, aproximadamente, e alcança até 1910; mais tarde foi retomada pelos familiares, em 1920, quando se inseriu manualmente, nas páginas centrais, ainda não utilizadas, uma precária ordenação alfabética digital. Na primeira parte, aquela que nos interessa, indicações de Charbonnier, Menuisier, Peintre bâtiment, American Petroleum Company, Tapisseur, Fabrique de Cordes et Etampes revezamse, quase sempre da mão do artista, com endereços de artistas, homens de imprensa, relações sociais, freqüentadores de exposições, ocasionais companheiros de viagem, encontrados no país ou no estrangeiro, nomes as mais das vezes explicitados com sucinta indicação suplementar, a fim de refrescar a memória. Se o Evenoepel que aparece na primeira página poderia ser o pintor de Le Café d' Harcourt e La Fête Nègre a Blidah, mas também notável ilustrador de Poe -, um artista com quem Alvim Corrêa apresenta sintonia na maneira de certo fazer pictórico e na abordagem irônica da temática do dia-a-dia - a morte de Evenoepel em 1899, na França, afasta a hipótese, tentadora, de um contacto pessoal entre os dois coetâneos, desde que nos parece de todo improvável um encontro anterior em Paris (onde ambos estudavam na mesma época) entre o aluno de Detaille e o aluno de Moreau. Mas o Khnopff que surge logo na página seguinte, em letra graúda e destacada, e tem o endereço retranscrito mais duas vezes adiante, indicando a importância afetiva que representava para o dono do caderno (apenas os Fritz Müller de Beaupré ali compartilham da mesma honra), trata-se sem dúvida do autor de L 'Incensoir e I lock my door upon myself, títulos involuntariamente irônicos nesta circunstância. Outros pintores de menor prestígio, mas com algum nome no tempo, revalorizados em nossos dias pelo desenvolvimento dos estudos sobre o Simbolismo nas artes visuais, também aparecem registrados mais adiante, mas sem especial demonstração de interesse: "De Groux, peintre" (Henry de Groux, filho do célebre realista Charles de Groux) e Degouve de Nunques, autores de obras cuja atmosfera se situava muito distante da criação perseguida por Alvim Corrêa. Com estes revezam-se, além de diversos fotógrafos e heliogravadores, alguns assinalados com lápis vermelho raccomandé, outras personagens expressivas: "Victor Rousseau, sculpteur", "Vallette, éditeur du Mercure de France", "Henry d'Avray" (depois corrigido para Davray - o tradutor francês de A Guerra dos Mundos), "H.G. Wells (Spade House, Sandgate)", "William Heinemann, éditeur de Londres", "Malveaux, typograveur", "Tallon \& Cie, Imprimeur Photograveur", "Vandamme, Imprimeur Photograveur", "Mlle. Art, artiste peintre"; Systermans, directeur du XXe siècle", "Léon Dommartin, directeur de Chronique", "Charles Didier, directeur du Cottage", "Mademoiselles Gessey (as duas velhas da Exposição Boute)", "M. Eyerman acheteur du 
Jour de Pluie", "Georges Lemmers, artiste peintre q. se trouvait chez Mlle. Art, "Pierre Petitjean (peintre rencontré dans le wagon au St. Gottard)", "Gustave de Graef (journaliste rencontré chez Lemmers)", "L. Moreels, dessinateur (del'ancienne Reforme)", "Gaudy, dessinateur"; Henri Strentz, poète rencontré sur bateau au lac Majeur", Léon Lucas, architecte", "Géo Bernier, peintre", Lemoine, critique d'art", “Thiriar, artiste peintre", "Ministre du Brésil O.L.", "Van der Hasselt, sculpteur", "J.R. Valentinelli peintre”, “J.P. de Jaager, sculpteur", "James Thiriar”. Endereços e indicações que fornecem uma segura panorâmica do relacionamento progressivo do jovem pintor, no ambiente belga e nos seus deslocamentos provocados pela doença, durante os anos decisivos da residência dele em Bruxelas e permitem esboçar mesmo o roteiro das suas atividades: 1902-1903 progressão do projeto de ilustrar A Guerra dos Mundos, contactos com a

Mercure de France, a fim de poder utilizar a versão Davray, subseqüente correspondência com Wells, precedendo a viagem a Londres em 1903; pesquisa das impressoras que trabalhavam com heliogravura e fotogravura; 1904-1905 - preparação da mostra da Salle Boute, contatos preliminares com a imprensa, registro dos elementos do público que demonstraram interesse pelo artista; registro do primeiro colecionador estranho que adquiriu obra do artista durante a exposição - Monsieur Eyerman - e registro do óleo (ou mais provavelmente desenho) por ele adquirido, Jour de Pluie, de certo flagrante urbano com o sainete próprio do artista, 190710 - contactos com outros artistas, como Georges Lemmers (que não deve ser confundido com o seu quase homônimo Georges Lemmen, o Eugène Grasset belga), conhecido em casa de Mademoiselle Art - "Art comme art" -, esta, por sua vez, malgrado o sobrenome arquetipiano de musa que arvorava, apenas outra artista do pincel. Provavelmente por intermédio de Lemmers, Alvim Corrêa terá entrado em contacto, além de Gustave de Graef, jornalista que encontrou em casa do confrade, com os desenhistas Moreels e Gaudy, com o crítico visual Lemoine e com os irmãos Willy e James Thiriar - pois tanto os dois Thiriar como Lemmers participarão da primeira coletiva do Sketch-Club, em abril de 1910. Muito doente embora, o nosso artista integrou o grupo dos expositores, na véspera mesmo da crise que o prostraria, de modo definitivo, em fins de maio. Em março de 1905, ainda de todo desconhecido no ambiente bruxelês, Henrique Alvim Corrêa havia corajosamente montado uma exposição individual que desejava apresentar, num retrospecto franco, seja da sua formação convencional, seja das novas e variadas preocupações que agora o instigavam. A paternalística resenha que o crítico do Journal de Bruxelles, E.J., dedicou à mostra, na edição de 12 de março, fornece flagrante 
expressivo da situação cultural do jovem Henrique perante aquele meio:

"La salle Boute semble particulièrement affectionée par les artistes étrangers; y voici M. Elvim Corréa [sic] faisant de la peinture militaire. Nous entendons par ces mots non seulement une certaine catégorie de sujets, mais encare tente une facture traditionelle, tout un genre. Pour que nul $n$ 'en ignore, au milieu de la salle trône un faisceau portant un casque prussien voisinant avec un képi français: c' est rappeler Detaille, de Neuville, les Dernières Cartouches... Il y a là un courage qui déjà mérite attention. Montrons -nous donc sympathiques à ces scènes militaires, parmilesquelles plusieurs sont inspirées par les guerres d' Extrême-Orient. Quelques paysages curieux, quelques figures étranges se rapprochent plus de l'art proprement dit. Une série de dessins pour illustrer une des oeuvres de Wells, ce Jules Verne des 'grandes personnes' témoignent d'une heureuse richesse d' imagination joint aux habilités tecniques coutumières."

Embora as demais notas da imprensa não tenham adotado esse tom, tanto Le Soir, La Gazette, L'Independance Belge e em especial La Chronique demonstraram interesse pelo expositor e penetração crítica diante da obra (a matéria da última folha, a mais longa, entremeia habilmente uma quase entrevista com agudo esboço de interpretação da personalidade criadora de Alvim Corrêa, valioso ainda hoje) -, não nos será difícil reconstituir a ansiedade do artista em relação a essas primeiras manifestações da crítica sobre a sua identidade visual, sobre a qual ele mesmo devia manter certa perplexidade. Já em 1910 devia ele ler quase com indiferença a notas sobre a coletiva de que participava, escrita pelo crítico de Le Soir: "En marge des grandes expositions dont on nous annonce l'ouverture prochaine, le Sketch-Club vient d'ouvrir la sienne en la salle du Studio, modeste mais combien intéressante, cependant. Les membres de ce Club, des artistes connus pour la plupart ..." E eis o comentarista a referir-se, com efeito, aos companheiros mais próximos com quem o nosso pintor conseguiu se acamaradar nos últimos anos, convívio de trabalho que um pouco explica a criação desse Sketch-Club: "les petites pages guerrières, très animées, de M. JamesThiriar", "paisages” de M. Willy Thiriar, "jolis dessins colorés de M.G. Lemmers" (por inevitável assimilação com o outro G. Lemmen, famoso, saiu impresso Lemmens). até concluir a rápida resenha: "Mais nous nous arrêtons plus longtemps encore devant les sanguines où, d' un crayon très sur, $M$. W atelet a rendu quelques élégantes visions féminines, et devant les dessins si originaux ou M. Alvin Corréa [sic] nous rappelle l' art d' un Rops". Assim, numa honrosa mediania, ao lado de conhecidos mais ou 20 menos recentes, o artista brasileiro encerrava sua 'carreira' artística na Bélgica de "La Libre Esthétique". 
Curioso o fato de que Alvim Corrêa tenha projetado, na adolescência, ser autor de telas monumentais e, aos trinta anos, à véspera da morte prematura, tenha aceitado inteiramente o fato de se haver realizado numa obra fragmentária. Pois, foi no fragmento, literalmente, - e muito antes que se admitisse e se teorizasse sobre a Estética do Fragmento, como se tornou corrente e até monótono, neste declínio do século XX - que o mais belga dos artistas brasileiros trabalhou com sutileza, ciência e criatividade, e numa obra fragmentária muito bela que ele se realizou.

Esse miniaturismo não foi uma solução buscada; o artista chegou a ele motivado por diversas circunstâncias, inclusive imperativos de saúde. O nível que ele conseguiu impor a cada um dos seus trabalhos, o artista só o alcançou depois de longo e sofrido esforço. Desvanecidas as grandes esperanças dos 17 anos, a veleidade de painelista épico ir-se-ia retrair numa revisão de um trabalho criativo que inflete em sentido intimista, servida por uma disciplina e um rigor intelectual sempre exigentes. À frustração do pintor "em grande" correspondeu a afirmação definitiva do desenhista com uma centelha de gênio; ao desmantelamento da superfície extensa, a profundidade da invenção e do sentido.

Desenvolvendo a sua virtualidade visionária - e o visionarismo permeia tudo o que fez - ele anima o menor dos seus desenhos com intransferível marca pessoal. O comentador bruxelês de La Chronique que, a 10 de abril de 1910, afirmava ser o nosso artista "um pesquisador e decantador de quintessências" sabia o que afirmava. Segundo ele Alvim Corrêa "abomina a banalidade e põe alma no mais despretensioso dos seus esboços. Artista raro, sobre o qual plana a psicologia um tanto pessimista e às vezes macabra de Baudelaire, antes mais nada buscava ele expressão nas suas máscaras, colocando nessas frontes um pensamento, nesses lábios um desejo. Alvim Corrêa é uma personalidade!"

Setenta anos depois dessas linhas, que conservam forte sabor de época, o interesse que nos provoca esse mesmo grafismo envolvente, algumas vezes arrebatado, quase sempre intenso e impetuoso, garante para o nosso autor a posição não apenas de um dos maiores desenhistas do nosso princípio do século brasileiro, mas a de figura maior no gênero. Se a obra pictórica de Alvim Corrêa, apesar da qualidade que apresenta, e do coeficiente de pesquisa que assume, constitui sempre uma tentativa (extremamente expressiva, aliás), o artista gráfico, pioneiro da gravura brasileira, conforme José Roberto Teixeira Leite revelava ao Brasil, em 1965, o desenhista privilegiado pôde fixar, no espaço breve de tempo que lhe foi concedido viver, um amplo registro temático e estilístico onde a 
poderosa inventividade dele demonstrou de uma vez por todas que seu nome permanecerá entre nós mais perene que a marca dos canhões que ele pintou quando mocinho e sobre o bronze dos quais desenhou o próprio busto numa caricatura.

São Paulo, agosto-setembro de 1981.

\author{
À memória de Eduardo, \\ que preservou com carinho \\ e restaurou com talento a \\ obra paterna, esperando para breve a apreciação \\ que o Brasil deve à pintura dess \\ e mestre secreto \\ Para Roberto, \\ poeta debaixo do signo perene de Hebe \\ sob o qual seu pai cerrou os olhos \\ Para Sergio, \\ com sentimento \\ fraterno
}

$O$ autor agradece de modo especial a Roberto e Georgina Alvim Corrêa, e a Sérgio Nepomuceno Alvim Corrêa, que permitiram examinar documentos inéditos e fotografias do arquivo de A.C. Agradece ainda a Pietro Maria Bardi e Anna Carboncini, do Museu de Arte de São Paulo, e a Leila Florence, bibliotecária doMASP; Maria de Lourdes Gentil, da Biblioteca de Arte do IDART paulistano; Maria Cristina Nery, da biblioteca do Jockey Club de São Paulo, sem os quais este trabalho não teria tido o apoio bibliográfico indispensável. 
188 - Remate de Males 32.2

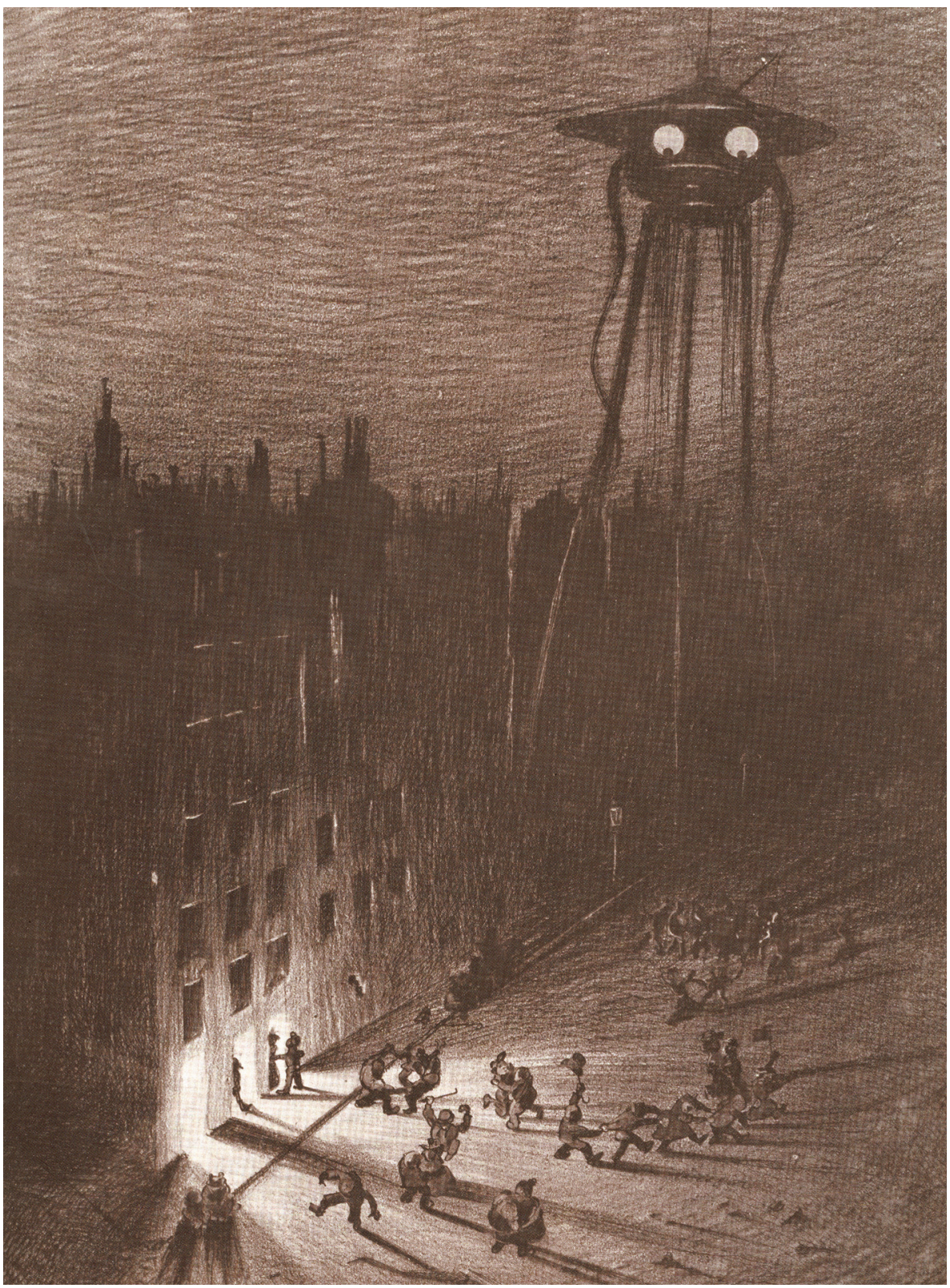




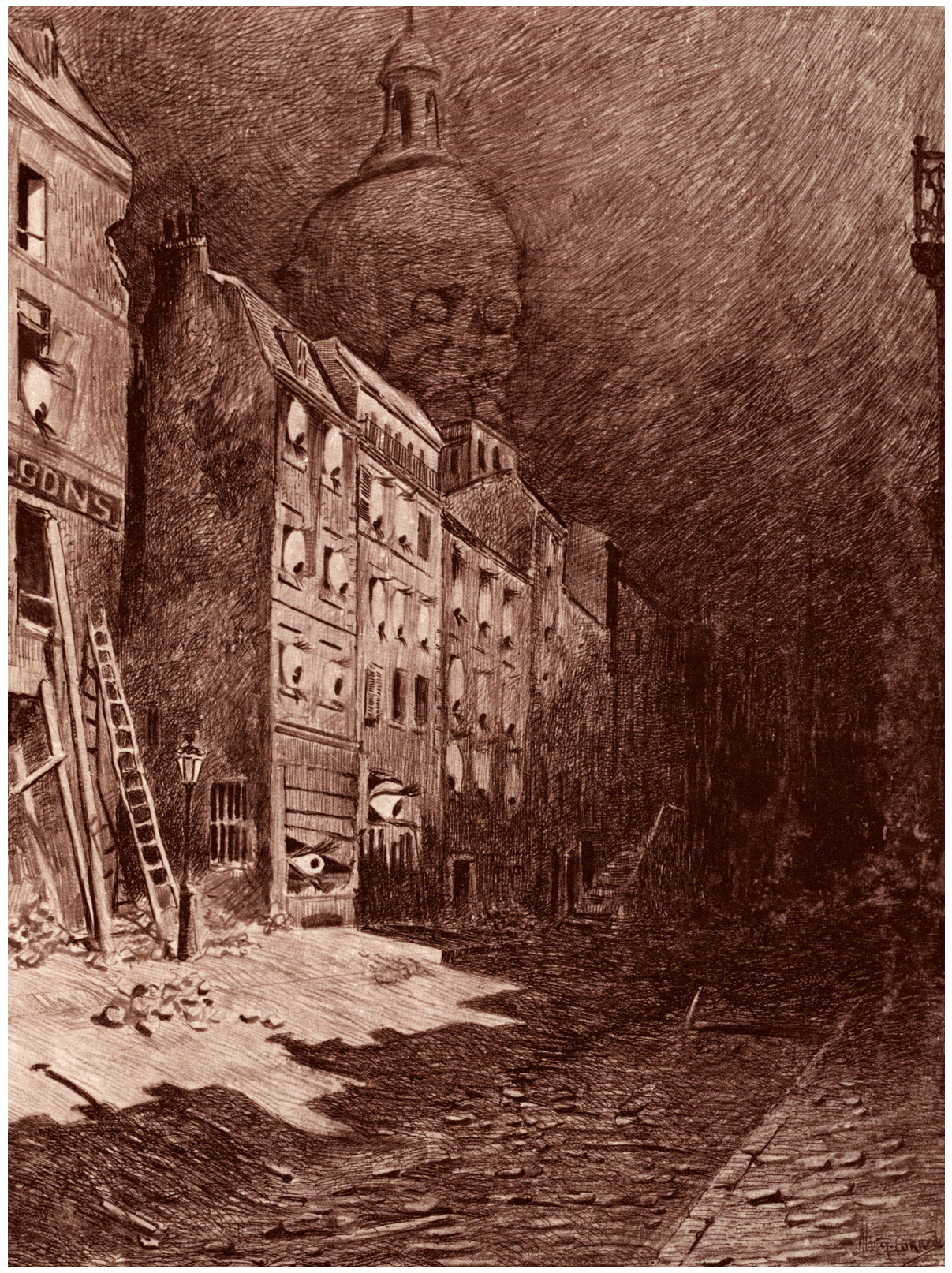


